\title{
The impact of tourism in a fragile wetland ecosystem in Angola: the Arco (Namibe) case study
}

\author{
A. O. Tavares ${ }^{1}$, M. A. Máquina ${ }^{2}$ \& M. H. Henriques ${ }^{3}$ \\ ${ }^{1}$ Earth Sciences Department and Centre for Social Studies, \\ Coimbra University, Portugal \\ ${ }^{2}$ Namibe Polytechnic Graduate School, Mandume ya Ndemofayo, \\ Namibe University, Angola \\ ${ }^{3}$ Earth Sciences Department and Geosciences Centre, \\ Coimbra University, Portugal
}

\begin{abstract}
Wetland areas, which are major tourist attractions, are one of the most fragile ecosystems in the world. This article assesses the environmental impacts of tourism activities, namely trekking, camping and leisure pursuits, in the Arco region in the Namibe Desert (Southwest Angola), close to the Atlantic coast. The River Curoca generates a wetland system of small permanent ponds creating a natural oasis, which attracts both domestic and foreign tourists and generates economic resources for the small local community. In order to evaluate the environmental impacts associated with tourism in the region, the magnitude, the spatial and temporal incidence of the impacts were estimated using an interaction matrix supported by a local population survey and an interview administered to regional stakeholders. The results emphasise the impacts associated with trekking in large groups and leisure parties. The study underlines the singularity and attractiveness of the area and the fact that, up to now, such activities seem to have had a minor impact and have led to only slight losses in terms of biodiversity. It also emphasises the need for certain structural and non-structural actions, namely promotion and protection measures, as a means of enhancing the environment in the Arco region.

Keywords: Wetland, tourism impact, interaction matrix, Arco region, Angola.
\end{abstract}




\section{Introduction}

Wetland areas, which are major tourist attractions, are one of the most fragile ecosystems in the world. Two different perspectives for tourism can be highlighted in these areas, one relating to the substantial environmental impacts and the importance of implementing appropriate protection measures (Dugan [1], the Ramsar Convention Secretariat [2]), and the other focussing on income opportunities for local people and indirect incomes in an environmental context (Turner et al. [3], Baker [4], Mbaiwa [5]). Since the Joint Declaration on Tourism and Environment (UNEP [6]), sustainable tourism has been emphasised as a solution for reducing the environmental threat posed by the growth of global tourism.

Different studies have highlighted the importance of wetlands as areas with specific conservation needs and have called for communal land tenure in the management of natural resources (Dugan [1], MINUA [7], Lili et al. [8]). In Africa, different wetland areas have been identified as supporting the development of tourism by combining social and environmental ethics (Dahlberg [9], Magole et al. [10], Baker [4] Mbaiwa [5]).

Parallel to this, natural resources, namely geological features, can be understood as the primary focus of a sustainable tourism which fosters environmental and cultural understanding, appreciation and conservation, and is locally beneficial (Dowling [11]).

This article assesses the perceived environmental impacts and expectations of the local population and stakeholders with regard to tourism activities in the Arco region wetlands in Namibe Province (Southwest Angola), based on the concept of Community Benefit Tourism Initiatives (Simpson [12]).

The area is located in the Namibe Desert, approximately 20 kilometres from the Atlantic coast. The region has a semi-desert climate and is intersected by the River Curoca, which has torrential characteristics. Due to its low transport capacity, the River Curoca generates a wetland system consisting of small permanent ponds creating a natural oasis and unique erosion landforms, which attracts both domestic and foreign tourists and generates important economic resources for the small local community.

This paper addresses the following questions: What are the environmental impacts and benefits of tourism from the point of view of local residents? What are the impacts of tourism activities and the land management requirements, from the stakeholder's point of view? Which forms of tourism have the greatest environmental impact? What measures should be pursued to ensure sustainable tourism in the area and income opportunities for its residents?

\section{General characterisation of the area}

The study area is located $73 \mathrm{~km}$ south of the capital of Namibe province, to which it is linked by a single paved road. Administratively the area is included in the municipality of Tômbwa, composed of thirteen villages. It is part of a morphological plateau intersected by rivers with intermittent torrential flow. The 
main river in the area is the Curoca, which has a basin area of around $9800 \mathrm{~km}^{2}$, characterised by uplifted mountains in the east and a sedimentary pediplan that extends to the Atlantic Ocean. There are hills with sedimentary layered rock and erosional forms with deep slopes on its right-hand margins, and sandy dunes created by aeolian transport on the left.

In addition to location, Figure 1 shows the contrasts and forms of erosion and sedimentation, as well as the fluvial deposit banks, bars, lakes and ponds. The Figure 2 shows the characteristic forms of the river banks resulting from water flow and aeolian erosion, namely deep excavated slopes, erosion arcs, and large rock falls, displaying a high scenic content (Pena dos Reis and Henriques [13]). In the lakes, ponds and stretches of the river fuelled by the torrential regime, the aquifers recharge and a characteristic flora and fauna develops in the June to August fog caused by the proximity of the sea, contrasting with the semi-desert areas (Máquina [14]).
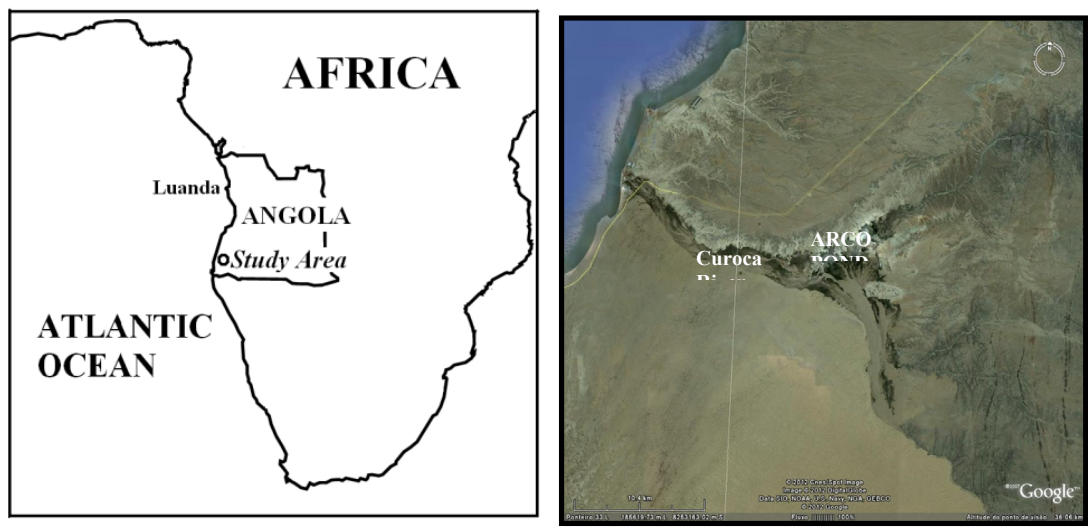

Figure 1: Location and satellite imagery of the study area GOOGLE ${ }^{\mathrm{TM}}$ (2007), showing the contrasting forms.

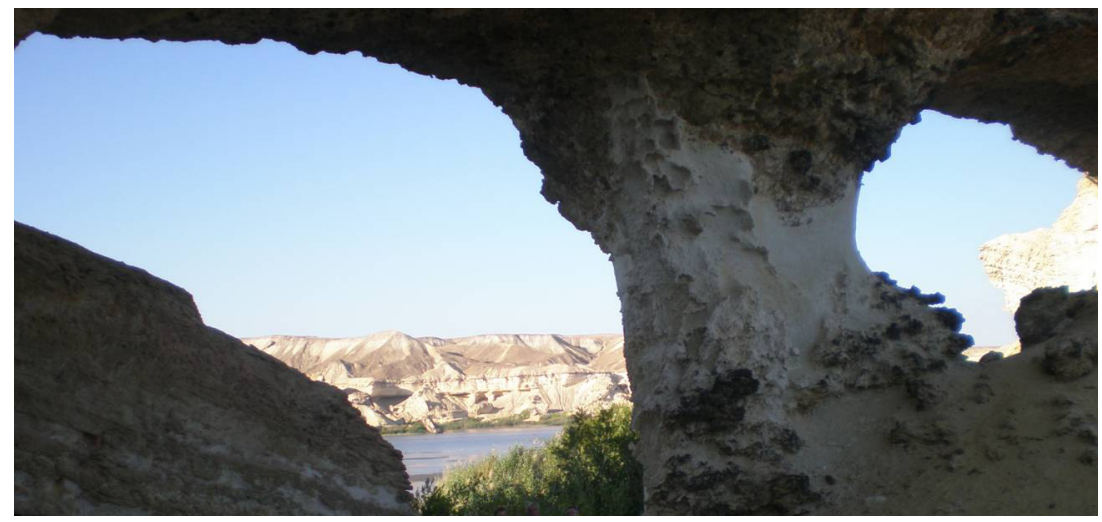

Figure 2: $\quad$ View of pond and typical erosion slope form. 
The region is part of the Namibe Reserve area, and has a remarkable range of flora in the banks, bars and margins of the river, including Phyla nodiflora, Osteospermum rigidum, Pluchea dioscoridis and, in the temporary ponds, Phragmites mauritianus and Salvadora persica communities. Some other species of Gramineae, Aizoaceas, Euphorbiacea and Chenopodiacea, are also present (PDIPN [15]). Some exotic plants can also be found, such as palm-of-range, mamonas (Ricinus comumunis), cyca (Cycas circinalis), bamboo (Bambusa oldhamii), black thorn (Acacia nilotica), white thorn (Acacia albida) and casuarina (Casuarina equisotifolia). The fauna is characterized by the presence of goat-of-range (Antidorcas marsupialis) and oryx (Oryx gazella), as well as ducks, frogs and rats.

The population of the Arco is of Bantu origin, resulting from the merger of the Kwepe and Kwanhoca ethno-linguistic groups (CEA [16]) and belongs to the Herero ethno-linguistic group (Malaquias [17]). The inhabitants live in thirty clans or families, and occupy the territory in a traditional way. Leadership belongs to the oldest person in the family group or clan. The main activities and livelihoods are based on livestock (cattle, goat and sheep), agriculture (subsistence farming), basketry, and trading traditional products.

The Arco region is visited by neighbouring national and foreign tourists most frequently in the summer, although it is difficult to quantify numbers and frequency as there are no controlling structures. However, the following types of visitors have been recorded: predominantly domestic visitors, for stays lasting a few hours, domestic visitors for longer stays, and an increasing number of foreign visitors staying just a few hours (Máquina [14]).

\section{Methodology}

Evaluating nature and its place in society, in particular in terms of the impact of tourism and the different actors involved (Reynolds and Braithwaite [18]) is a growing research topic. The analysis of territorial potential and cohesion is framed within policy measures related to territorial efficiency, quality and identity (Golobic and Marot [19]).

Two analytical tools were designed in order to assess the basic environmental status and the impact of various forms of tourism in the Arco region.

The first was a survey, administered to the entire population aged 18 or over. Focussing on environmental resources and socio-economic activities, as well as the pressures on the Curoca wetlands, it contained a total of 45 questions organised into 3 sections, namely: a characterisation of the respondents; their assessment of the environmental impacts associated with flooding, river and wet system dynamics, land use, livelihoods, quality of soil and water resources, mineral resources, building materials, air pollution, and biotic evolution and biodiversity; their evaluation of tourist activities and recent developments in the Arco territory.

The second tool was used with the stakeholders and local and regional actors in charge of managing the Arco and aimed to evaluate the stakeholders' perceptions of the constraints and capacity of the territory. A survey containing 
open questions was designed and administered to 15 administrative and political actors, obtaining a total of 10 final responses. The tool comprised 10 questions focussing on characterisation of the respondents, their identification of the values and dynamics of the territory, their proposed measures for promoting sustainable development and management, and their perceptions of the impacts associated with tourism activities.

After combining the results obtained from both tools, a tourism impact assessment was produced. An interaction matrix incorporating activities and environmental elements and sub-elements was created to carry out the evaluation. This evaluation was supported by the Leopold et al. [20] methodology, applied by Cunha et al. [21]; Abdon [22] and Gracioli and Rocha [23] to generate the dimensional interaction between elements of the environment (earth, air, water and life) - as well as sub-elements (morphology, soil, rock, air, climate, surface water, groundwater, flora, fauna, landscape, health, economics and cultural aspects) - and the anthropogenic actions resulting from tourist activities.

The intensity of the interaction was evaluated in terms of three separate aspects involving an analysis of three positive or negative levels of magnitude for the impact of an activity or the extent of its effect on environmental elements. The interaction also included a temporal impact analysis representing three levels of recovery time from an impact, and its spatial incidence, assessing the scale of the impact on a local, regional or national level.

\section{Data from the resident survey}

The data obtained from the first survey (covering residents aged 18 or over) revealed that the population consists of large families, whose economic activities vary according to the seasons, with the majority involved in communal agricultural work, fishing, collecting firewood, drying fish and handicrafts.

The residents highlighted the importance of the Curoca river floods in terms of preserving the wetland system, and referred to a recent increase in the number of floods. The responses also revealed that, in their opinion, the areas and facilities for agriculture and grazing have remained stable over time.

When asked about the quality of water resources for personal consumption, they cited direct use from the pond, with some recent loss of quality detected in associated diseases, although no relationship seemed to be established between this and agricultural and grazing practices. References were also made to air pollution, caused by natural processes involving sand and dust transported by wind, but also by traffic due to tourism.

There was no acknowledgement of any loss of biodiversity; instead, the residents considered the vegetation cover in the area surrounding the main pond had been enriched.

The respondents confirmed the increasing number of tourists, as well as the longer amounts of time spent in the region. The maximum stay by tourists was described as not exceeding one journey usually limited to a few hours. The 
inhabitants of Arco identified high noise levels and litter as the main impacts associated with the tourism.

In conclusion, the resident survey highlighted the importance of the river and the dynamics of the wetland system, and the low environmental pressure associated with biotic and abiotic resource management. They emphasised tourist activities in contrasting ways, both as generating income and as environmental impacts in the Arco region.

\section{Data from the stakeholders survey}

The stakeholders who responded to the survey can be classified into two separate groups: the group familiar with Arco for less than 10 years, and the group that had known the area for several decades, in both cases citing an average of three visits to the area per year. When asked about their perceptions of the Arco, 58 different answers were obtained, which were grouped, on the basis of content analysis, into three frames (Table 1) referring to the uniqueness of the area, the environmental features and the identification of scenic elements.

Table 1: Content frame analysis from the stakeholders inquiry.

\begin{tabular}{|c|c|c|}
\hline \multicolumn{3}{|c|}{ Contents } \\
\hline Uniqueness & Environmental elements & Scenic elements \\
\hline $\begin{array}{c}\text { Singular, unusual, } \\
\text { particular, unique, different } \\
\text { (2), specific, particular (3), } \\
\text { peculiar, of scientific value, } \\
\text { of ecological value }\end{array}$ & $\begin{array}{c}\text { Pond (7), desert (3), geological } \\
\text { formations, flooding (2), } \\
\text { geography, topography (3), } \\
\text { wetland, wildlife, fauna, flora, } \\
\text { morphology (4), water, } \\
\text { biodiversity (3), migratory birds, } \\
\text { sound of birds, sound of frogs, } \\
\text { fresh air, rocks }\end{array}$ & $\begin{array}{c}\text { Doors } \\
\text { shapes, beautiful, beauty } \\
\text { (4), landscape, green, } \\
\text { lovely }\end{array}$ \\
& & \\
\hline
\end{tabular}

When asked about recent changes or environmental impacts, the stakeholders cited the biotic and abiotic degradation of the environment, reduction in the water levels of the pond, over-exploitation of water resources, increased flows of tourists and the deterioration of the local environmental due to tourism.

When asked to propose development tools, the respondents indicated different and contrasting measures which may be organised into structural and nonstructural measures, as illustrated in Figure 3.

The list included non-structural aspects addressing both inventory and environmental valuation, land use planning and the legal framework, as well as information campaigns and tourism development and promotion.

When asked about the impacts associated with tourism, 3 respondents cited deterioration of the ecosystem, 3 deterioration of natural features, 2 social conflict, and one individual said that there was no impact involved.

Tourism is seen by most stakeholders as a form of local economic development and a source of local income. The respondents identified the institutions that should intervene in future developments as the following: the provincial government, the local government, the tourism administration office, 
leaders of environmental organisations and other experts. They also identified the involvement of traditional leaders and the local administration, in addition to elders and the general population, as being equally important.

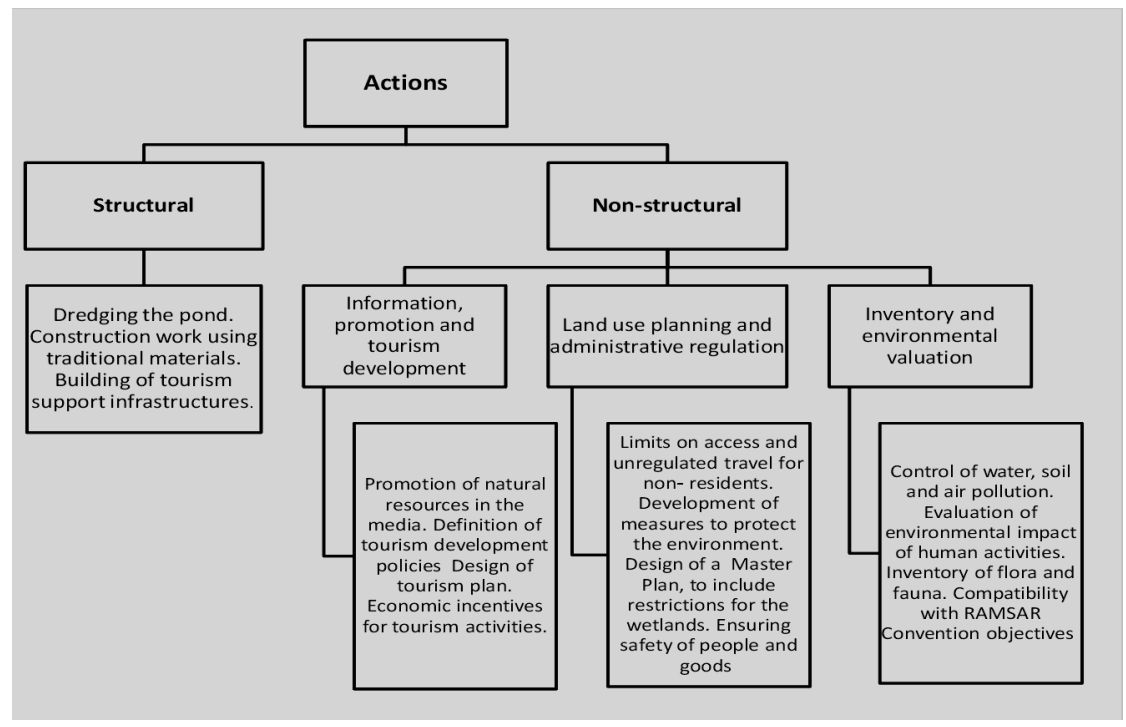

Figure 3: Stakeholders' proposed development tools.

The respondents unanimously felt there was a need to introduce restrictions on logging, hunting, the use of motor boats and the construction of new housing. Restricting the access of non-residents to the Arco region was not considered necessary, although the need to limit entry to the region and make adjustments to traffic conditions and the management of waste, including plastic and glass products, was emphasised. Compatibility with the RAMSAR Convention objectives was considered important by some respondents.

\section{The tourism activities impact matrix}

In order to assess the weaknesses and potential of natural resources in the Arco region in terms of anthropogenic activities, particularly those resulting from the increased number of tourists, the length of time spent in the area and the activities involved, a matrix was created to show the interaction between environmental elements and the impact of different tourism activities.

The Leopold method (Leopold et al. [20]) was applied, assessing the focus and magnitude of the impact and its spatial and temporal incidence, supported by the results of the resident survey, stakeholder inquiry, and field work recognition.

The following activities were considered in the assessment of tourism:

1 - visitors trekking in small groups (up to 5 visitors); 
2 - visitors trekking in large groups (more than five visitors);

3 - unplanned camping by visitors for a period of more than 24 hours;

4 - leisure parties associated with large concentrations of people during the day and/or at night, staying several hours or days.

The results of the interaction matrix are presented in Figure 4, showing the positive impacts in shaded cells and the negative impacts in white cells.

\begin{tabular}{|c|c|c|c|c|c|c|c|c|c|c|c|c|c|c|c|c|c|c|}
\hline \multirow[b]{2}{*}{ 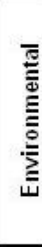 } & \multirow[b]{2}{*}{$\frac{\stackrel{\infty}{\bar{\omega}}}{\frac{\bar{\sigma}}{\omega}}$} & \multirow[b]{2}{*}{ Impacts } & \multicolumn{4}{|c|}{ Magnitude } & \multicolumn{4}{|c|}{ Spatial incidence } & \multicolumn{4}{|c|}{ Temporal incidence } & \multicolumn{4}{|c|}{ Accumulated Score } \\
\hline & & & 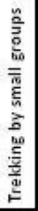 & 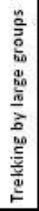 & 总 & 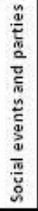 & 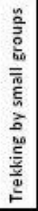 & 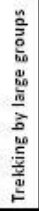 & 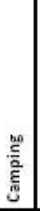 & 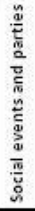 & 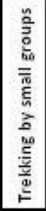 & 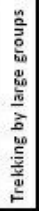 & 势 & 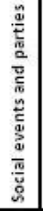 & 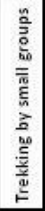 & 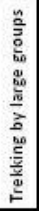 & .0 & 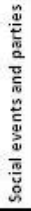 \\
\hline \multirow{7}{*}{ 立 } & \multirow{6}{*}{ 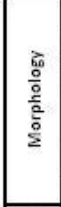 } & Rate of erosion & 2 & 3 & 3 & 3 & $\mathrm{~L}$ & $\mathrm{~L}$ & $\mathrm{~L}$ & $L$ & $P$ & $P$ & $\mathrm{P}$ & $\mathrm{P}$ & 6 & 7 & 7 & 7 \\
\hline & & Rate of sedimentation & 2 & 3 & 3 & 3 & $\mathrm{~L}$ & $\mathrm{~L}$ & $\mathrm{~L}$ & $\mathrm{~L}$ & $\mathrm{P}$ & $\mathrm{P}$ & $\mathrm{P}$ & $\mathrm{P}$ & 6 & 7 & 7 & 7 \\
\hline & & Rockfall & 1 & 2 & 2 & 3 & $\mathrm{~L}$ & $\mathrm{~L}$ & L & L & $\mathrm{P}$ & $\mathrm{P}$ & $\mathrm{P}$ & $\mathrm{P}$ & 5 & 6 & 6 & 7 \\
\hline & & $\begin{array}{c}\text { Changes in river banks and } \\
\text { pond }\end{array}$ & 1 & 2 & 2 & 2 & $\mathrm{~L}$ & L & L & $\mathrm{L}$ & $x$ & $x$ & $x$ & $\mathrm{x}$ & 4 & 5 & 5 & 5 \\
\hline & & Arable soil destruction & 1 & 2 & 2 & 2 & $\mathrm{~L}$ & $\mathrm{~L}$ & $\mathrm{~L}$ & $L$ & $T$ & $T$ & $T$ & $x$ & 3 & 4 & 4 & 5 \\
\hline & & Contamination & 1 & 2 & 2 & 3 & $\mathrm{~L}$ & $\mathrm{~L}$ & L & L & $T$ & $x$ & $T$ & $x$ & 3 & 5 & 4 & 6 \\
\hline & $\frac{y}{\check{c}}$ & $\begin{array}{l}\text { Enhancement of mineral } \\
\text { resources }\end{array}$ & 3 & 3 & 3 & 3 & N & N & $\mathrm{N}$ & N & $x$ & $x$ & $x$ & $\mathrm{x}$ & 8 & 3 & 8 & 8 \\
\hline \multirow{3}{*}{\multicolumn{2}{|c|}{$\overline{\bar{\alpha}}$}} & Dust & 1 & 3 & 3 & 3 & $\mathrm{~L}$ & $\mathrm{~L}$ & $\mathrm{~L}$ & $\mathrm{~L}$ & $T$ & $\mathrm{~T}$ & $\mathrm{~T}$ & $\mathrm{~T}$ & 3 & 5 & 5 & 5 \\
\hline & & Smell & 1 & 2 & 2 & 3 & $\mathrm{~L}$ & $\mathrm{~L}$ & L & L & $\mathrm{T}$ & $\mathrm{T}$ & $T$ & $T$ & 3 & 4 & 4 & 4 \\
\hline & & Noise & 2 & 2 & 2 & 3 & $\mathrm{~L}$ & $\mathrm{~L}$ & $\mathrm{~L}$ & $\mathrm{~L}$ & $T$ & $T$ & $T$ & $T$ & 4 & 4 & 4 & 5 \\
\hline \multirow{3}{*}{\multicolumn{2}{|c|}{$\stackrel{\overline{ \pm}}{\stackrel{4}{3}}$}} & Surface Water Quality & 1 & 2 & 2 & 3 & $\mathrm{~L}$ & $\mathrm{~L}$ & $\mathrm{~L}$ & $R$ & $\mathrm{~T}$ & $T$ & $T$ & $\mathrm{x}$ & 3 & 4 & 4 & 7 \\
\hline & & Water Eutrophication & 1 & 1 & 1 & 2 & $\mathrm{~L}$ & $\mathrm{R}$ & $\mathrm{L}$ & $R$ & $x$ & $\mathrm{x}$ & $\mathrm{x}$ & $x$ & 4 & 5 & 4 & 6 \\
\hline & & Groundwater quality & 1 & 1 & 1 & 2 & $L$ & L & L & L & $x$ & $x$ & $x$ & $\mathrm{x}$ & 4 & 4 & 4 & 5 \\
\hline \multirow{10}{*}{$\stackrel{\Perp}{\Xi}$} & \multirow{4}{*}{$\frac{\mathrm{g}}{\frac{0}{4}}$} & Forest occupation & 1 & 2 & 2 & 2 & $\mathrm{~L}$ & $\mathrm{~L}$ & $\mathrm{~L}$ & $\mathrm{~L}$ & $T$ & $T$ & $T$ & $T$ & 3 & 4 & 4 & 4 \\
\hline & & Floras based & 1 & 2 & 2 & 2 & $\mathrm{~L}$ & $\mathrm{~L}$ & $\mathrm{~L}$ & $\mathrm{~L}$ & $\mathrm{~T}$ & $\mathrm{~T}$ & $T$ & $\mathrm{~T}$ & 3 & 4 & 4 & 4 \\
\hline & & Aquatic plants & 1 & 2 & 1 & 2 & $\mathrm{~L}$ & $L$ & $\mathrm{~L}$ & $\mathrm{~L}$ & $T$ & $\mathrm{~T}$ & $T$ & $\mathrm{~T}$ & 3 & 4 & 3 & 4 \\
\hline & & Established flora & 1 & 2 & 2 & 2 & $\mathrm{~L}$ & $\mathrm{~L}$ & $\mathrm{~L}$ & L & $x$ & $x$ & $x$ & $x$ & 4 & 5 & 5 & 5 \\
\hline & \multirow{6}{*}{ 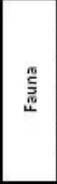 } & Fauna & 1 & 2 & 2 & 3 & $\mathrm{~L}$ & $\mathrm{~L}$ & $\mathrm{~L}$ & $\mathrm{~L}$ & $\mathrm{~T}$ & $\mathrm{~T}$ & $\mathrm{~T}$ & $\mathrm{~T}$ & 3 & 4 & 4 & 5 \\
\hline & & Land animal population & 1 & 2 & 2 & 3 & $\mathrm{~L}$ & $\mathrm{~L}$ & $\mathrm{~L}$ & $\mathrm{~L}$ & $\mathrm{~T}$ & $T$ & $\mathrm{~T}$ & $T$ & 3 & 4 & 4 & 5 \\
\hline & & Aquatic animal population & 1 & 2 & 1 & 2 & $\mathrm{~L}$ & $\mathrm{~L}$ & $\mathrm{~L}$ & $\mathrm{~L}$ & $x$ & $\mathrm{x}$ & $x$ & $x$ & 4 & 5 & 4 & 5 \\
\hline & & Migration & & 1 & & 1 & & $R$ & & $R$ & & $\mathrm{~T}$ & & $T$ & & 4 & & 4 \\
\hline & & Food chain & 1 & 2 & 1 & 2 & $\mathrm{~L}$ & $\mathrm{~L}$ & $\mathrm{~L}$ & $\mathrm{~L}$ & $T$ & $\mathrm{~T}$ & $\mathrm{~T}$ & $\mathrm{~T}$ & 3 & 4 & 3 & 4 \\
\hline & & Endangered fauna & 1 & 2 & 2 & 2 & $\mathrm{~L}$ & $\mathrm{~L}$ & $\mathrm{~L}$ & $\mathrm{~L}$ & $\mathrm{~T}$ & $T$ & $T$ & $\mathrm{~T}$ & 3 & 4 & 4 & 4 \\
\hline \multirow{2}{*}{\multicolumn{2}{|c|}{ Landscape }} & Aesthetic changes & 1 & 2 & 1 & 2 & $\mathrm{~L}$ & $\mathrm{~L}$ & $\mathrm{~L}$ & $\mathrm{~L}$ & $\mathrm{P}$ & $P$ & $\mathrm{P}$ & $\mathrm{P}$ & 5 & 6 & 5 & 6 \\
\hline & & Impact on feature & 1 & 2 & 3 & 2 & $\mathrm{~L}$ & $\mathrm{~L}$ & L & L & $T$ & $T$ & $T$ & $T$ & 3 & 4 & 5 & 4 \\
\hline \multirow{8}{*}{$\frac{z}{\tilde{u}}$} & \multirow{5}{*}{ 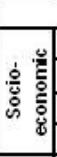 } & Sanitation & 1 & 2 & 2 & 2 & $\mathrm{~L}$ & $L$ & $\mathrm{~L}$ & $\mathrm{~L}$ & $\mathrm{~T}$ & $\mathrm{~T}$ & $\mathrm{~T}$ & $\mathrm{~T}$ & 3 & 4 & 4 & 4 \\
\hline & & Economic aspects & 1 & 1 & 2 & 2 & $\mathrm{~L}$ & $R$ & $\mathrm{~L}$ & $R$ & $T$ & $T$ & $T$ & $T$ & 3 & 4 & 4 & 5 \\
\hline & & Health and education facilities & 2 & 1 & 2 & 1 & $\mathrm{~L}$ & $\mathrm{~L}$ & $\mathrm{~L}$ & $\mathrm{~L}$ & $x$ & $x$ & $x$ & $x$ & 5 & 4 & 5 & 4 \\
\hline & & Social conflicts & 2 & 3 & 2 & 3 & $\mathrm{~L}$ & $\mathrm{~L}$ & $\mathrm{~L}$ & $\mathrm{~L}$ & $\mathrm{~T}$ & $\mathrm{~T}$ & $T$ & $\mathrm{~T}$ & 4 & 5 & 4 & 5 \\
\hline & & Solidarity and cohesion & & & & 1 & & & & $L$ & & & & $T$ & & & & 3 \\
\hline & \multirow{3}{*}{$\frac{\mathscr{y}}{\frac{2}{3}}$} & Cultural aspects & 1 & 2 & 1 & 1 & H & N & N & $\mathrm{N}$ & $x$ & $x$ & $x$ & $x$ & 6 & 7 & 6 & 6 \\
\hline & & Heritage & 1 & 2 & 1 & 3 & $\mathrm{~L}$ & $\mathrm{~L}$ & $\mathrm{~L}$ & $\mathrm{~L}$ & $P$ & $\mathrm{P}$ & $\mathrm{P}$ & $\mathrm{P}$ & 5 & 6 & 5 & 7 \\
\hline & & Ethnography & 1 & 1 & 1 & 1 & $\mathrm{~L}$ & $\mathrm{~L}$ & $\mathrm{~L}$ & $\mathrm{~L}$ & $\mathrm{P}$ & $\mathrm{P}$ & $\mathrm{P}$ & $\mathrm{P}$ & 5 & 5 & 5 & 5 \\
\hline
\end{tabular}

Figure 4: Environmental interaction matrix for tourism activities in the Arco region. 
The results indicate that the only positive aspects associated with the different tourism-related activities are the exploitation of mineral resources, given the uniqueness of the landscape and the present forms of erosion, associated with enhancement of the natural heritage, and the improved economic conditions and levels of education and culture resulting from interaction with other communities.

The higher negative impacts are associated with erosion and sedimentation, together with the emergence of social conflict.

Overall it can be observed that the negative impacts are related in particular to social events (score -66), the movement of large groups (score -56) and camping (scores -50). The impacts associated with the movement of visitors in small groups are lower, with a score of -31 .

The evaluation of spatial distribution reveals that most of the negative impacts are local, with the exception of surface water eutrophication and wildlife migration, whereas the positive impacts have a wider spatial distribution.

The evaluation of the temporal incidence shows a great diversity in terms of the reversal of impacts. Morphology, water, landscape, heritage and cultural factors generally have a long-term or permanent impact, although most activities cause only temporary impacts. It can therefore be considered that tourism activities have a widely varying impact in terms of their temporal and spatial incidence, although trekking by large groups and leisure parties represents the greatest negative impact.

In terms of a composite analysis, it may be stated that the evaluation of three aspects (magnitude, and temporal and spatial incidence,) highlights the following impacts and their related total scores:

Leisure parties and social events with a high concentration of people negative score (-118)

Trekking by large groups of visitors - negative score (-109)

Unplanned camping - negative score (-98)

Trekking by small groups of visitors - a negative score (-80).

In general, the Arco interaction matrix therefore indentifies social events associated with leisure parties and involving large concentrations of people as the activity that produces the greatest impact, and also highlights abiotic environmental elements related to geological materials, cliff instability and natural landscape forms as the factors most likely to create environmental degradation.

\section{Conclusions}

On the basis of the results obtained from the two analytical tools administered to residents and stakeholders, the Arco region presents the environmental characteristics of a wetland system that merits conservation.

The different actors expressed different opinions on tourism. Whereas the residents believed that it only creates slight pressure on resources and biodiversity, despite stressing that the gradual increase in tourist numbers and time spent in the region increases certain impacts, the management stakeholders 
highlighted the uniqueness, great scenic value and potential environmental characteristics of the region, and considered tourism a key activity in improving quality of life and incomes for local residents. The range of uncertainty in the analysis may reflect methodological obstacles associated with the indicators used, or may also be part of a rational decision-making process for the development of tourism activities (Hughes [24]).

Both groups of actors also emphasised two simultaneous strategies that were, to some extent, contradictory with regard to tourism and included the construction of new infrastructures and improved road access, as well as measures to preserve environmental assets. Those different perspectives and underlying precautionary principles are recognised by Reynolds and Braithwaite [18], and are evaluated in a similar geographic context by Mbaiwa [5], where changes in community livelihoods and lifestyles are balanced with top-down policy strategies.

As pointed out by Lili [8], the analysis of the interaction matrix for tourist activities and environmental elements suggests:

- There are fewer environmental elements with positive than negative impacts, and the former are associated with the recovery of mineral resources and heritage, as well as improvements to education and health care.

- The environmental elements with major negative impacts are associated with erosion and sedimentation, as well as the instability of the cliffs and landmass movements;

- The tourist activities that cause the greatest impacts are leisure parties and trekking by large groups of people;

- The tourist activities that involve trekking by small numbers of people and unplanned camping seem to have a lower impact on the environment.

The results also show that the greatest weaknesses are associated with abiotic environmental elements of the wetland system, including those associated with processes that shape the landscape.

- Finally, the Arco region offers unique landscape features that are compatible with tourism activities, although some of the latter, due to their environmental impact, should be reduced or mitigated. As Lili [8] points out, the impact of wetland tourism and management has an important relationship with tourist behaviour and facilities.

A balanced strategy that takes residents' demands into account, as well as the need to promote and develop tourism, planning tools and environmental conservation, should be designed, discussed and implemented by all the actors, and framed within the concept of national development policies, as suggested by Golobic and Marot [19]. The apparently diverging perceptions of residents and stakeholders concerning the status of the environment and the importance of tourism activities should be taken into account in future public management strategies, as indicated by Simpson [12] aimed at the promotion of sustainable development for the Arco wetland ecosystem. 


\section{References}

[1] Dugan, P., Wetlands in danger: a world conservation atlas, New York, Oxford University Press, 187 p., 1993.

[2] Ramsar Convention Secretariat, The Ramsar Convention Manual: a guide to the Convention on Wetlands (Ramsar, Iran, 1971), $5^{\text {th }}$ ed. Ramsar Convention Secretariat, Gland, Switzerland, 2011.

[3] Turner, R.K.; van den Bergh, J.C.J.M.; Söderqvist, T.; Barendregt, A.; van der Straaten, J.; Maltby, E.; van Ierland, E.C., Ecological-economic analysis of wetlands: scientific integration for management and policy, Ecological economics, 35, pp.7-23, 2000.

[4] Baker, N.J., Sustainable wetland resource utilization of Sango Bay trough Eco-Tourism development, African Journal of Environmental Science and Technology, 2(10), pp.326-335, 2008.

[5] Mbaiwa, J.E., Changes on traditional livelihood activities and lifestyles caused by tourism development in the Okavango Delta, Botswana, Tourism Management, 32, pp.1050-1060, 2011.

[6] World Tourism Organization and United Nations Environmental Programme, Join Declaration between World Tourism Organization and United Nations Environmental Programme, Madrid, 1982.

[7] MINUA, Documento para a Discussão da Política Nacional de Zonas Húmidas para Angola, Ministério do Urbanismo e Ambiente, Luanda, 36 p., 2006.

[8] Lili, P.; Lijuan, C.; Ming, W., Tourist Behaviors in Wetland Park: A Preliminary Study in Xixi National Wetland Park, Hangzhou, China, Chin. Geogra. Sci., 20(1), pp.66-73, 2010.

[9] Dahlberg, A., Local resource use, nature conservation and tourism in Mkuze wetlands, South Africa: A complex weave of dependence and conflict, Danish Journal of Geography, 105(1), pp.43-55, 2005.

[10] Magole, L.; Borgtoft Pedersen, H.; Klinte, L., An introduction to the Okavango Delta Management Plan. HOORC and DEA, Maun, Botswana, 2009.

[11] Dowling, R.K., Geotourism's Global Growth, Geoheritage, SpringerVerlag, 13 p., 2010.

[12] Simpson, M.C., Community Benefit Tourism Initiatives - A conceptual oxymoron?, Tourism Management, 29, pp.1-18, 2008.

[13] Pena dos Reis, R. and Henriques, M. H., Approaching an integrated qualification and evaluation system of the geological heritage. Geoheritage, 1(1), pp.1-10, 2009.

[14] Máquina, M. A., Arco (Namibe, Angola): Potencialidades e fragilidades do território, MSc Thesis, University of Coimba, Portugal, 69 p., 2010.

[15] PDIPN, Plano de Desenvolvimento Integrado da Província do Namibe, Governo Provincial do Namibe, Neto, A. (Coord.), 100 p., 2007.

[16] CEA, História de Angola, Centro de Estudos Angolanos, Edições Afrontamento, Argélia, 176p., 1965. 
[17] Malaquias, A., Ethnicity and conflict in Angola. Prospects for reconciliation. In: J Cilliers, C Dietrich (Eds.), Angola's war economy: The role of oil and diamonds, Institute for Security Studies, Pretoria, South Africa, pp.95-113, 2000.

[18] Reynolds, P.C.; Braithwaite, D., Towards a conceptual framework for a wildlife tourism, Tourism Management, 22, pp.31-42, 2001.

[19] Golobic, M.; Marot, N., Territorial impact assessment: Integrating territorial aspects in sectoral policies, Evaluation and Program Planning, 34, pp.163-173, 2011.

[20] Leopold, L.B., Clarke, F.E., Hanshaw, B.B. and Basley, J.E., A procedure for evaluating environmental impact, United States Geological Survey Circular, 645, Washington, 13 p., 1971.

[21] Cunha, L.; Soares, A.F.; Tavares, A.; Almeida, A.C. and Santos, J.G., Intervenções Recentes e Avaliação de Impactes Ambientais no Baixo Mondego, Cadernos de Geografia, 18, pp.39-52, 1999.

[22] Abdon, M., Os impactos ambientais no meio físico - erosão e assoreamento na bacia hidrográfica do rio Taquari, MS, em decorrência da pecuária, Doctoral Thesis, Universidade de S. Paulo, São Carlos, 302 p., 2004.

[23] Gracioli, C.R. and Rocha, J.S., Impactos Ambientais na microbacia hidrográfica do rio Vacacaí-Mirim em Santa Maria, RS, Ambiência, Guarapuava, PR, 4 (2), pp.251-263, 2008.

[24] Hughes, G., Environmental indicators, Annals of Tourism Research, 29(2), pp.457-477, 2002. 